Jurnal Konstruksi Hukum | ISSN: 2746-5055

Vol. 2, No. 2, Mei 2021, Hal. 418-423| Tersedia online di

https://www.ejournal.warmadewa.ac.id/index.php/jukonhum

DOI: https://doi.org/10.22225/jkh.2.2.3266.418-423

\title{
KEBIJAKAN PEMERINTAH DALAM MEMBERIKAN INSENTIF PAJAK PENGHASILAN PASAL 21 KEPADA WAJIB PAJAK TERDAMPAK PANDEMI COVID-19
}

\author{
I Putu Widya Laksana Pendit, I Nyoman Putu Budiartha, Ida Ayu Putu Widiati \\ Fakultas Hukum Universitas Warmadewa, Denpasar-Bali, Indonesia \\ pendit.widyalaksana@gmail.com, budiarthaputu59@gmail.com, idaayupuruwidiati@gmail.com
}

\begin{abstract}
Abstrak
Pandemi covid-19 telah berlangsung sejak akhir tahun 2019 dan berdampak sangat besar di bidang kesehatan, sosial, dan resesi ekonomi di Indonesia. Pemerintah perlu mengambil kebijakan untuk mengantisipasi permasalahan tersebut melalui kebijakan fiskal. Salah satu kebijakan yang dikeluarkan yaitu pemberian insentif pajak penghasilan pasal 21 kepada pekerja terdampak. Permasalahan penelitian ini mencakup substansi kebijakan pemerintah dalam pemberian insentif pajak penghasilan pasal 21, dan dampak pemberian insentif pajak penghasilan pasal 21 bagi para pekerja. Metode penelitian yang digunakan adalah metode penelitian hukum normatif, dengan pendekatan masalah secara perundang-undangan dan konseptual. Teknik pengumpulan bahan hukum dilakukan dengan mencatat, mengidentifikasi, menginventarisasi, dan menyusun sesuai dengan jenis bahan hukum yang ada. Berdasarkan hasil penelitian, ditemukan bahwa Pemberian insentif pajak penghasilan Pasal 21 dan ditanggung Pemerintah mempunyai persyaratan khusus mengenai kategori usaha dan besaran gaji pekerja yang berhak mendapatkan insentif. Hal ini diatur dalam Peraturan Menteri keuangan dan petunjuk pelaksanaannya melalui surat Direktorat Jenderal Pajak Nomor SE-47/PJ/2020. Adapun dampak pemberian insentif ini dapat meningkatkan pendapatan pekerja karena pajak penghasilan Pasal 21 ditanggung pemerintah dan membantu pekerja mempertahankan daya beli. Dengan demikian, dapat disimpulkan bahwa pemberian pajak penghasilan pasal 21 yang ditanggung oleh pemerintah memiliki dampak yang cukup baik terhadap para pekerja yang memenuhi kriteria dan syarat, sehingga para pekerja juga dapat mendapatkan insentif yang sesuai dengan pekerjaannya serta mampu menunjang kebutuhan hidupnya.
\end{abstract}

Kata kunci: Covid-19; Insentif Pajak; Kebijakan Pemerintah; PPh Pasal 21; Wajib Pajak.

\begin{abstract}
The Covid-19 pandemic has been going on since the end of 2019 and has had a huge impact in the health, social and economic recession in Indonesia. The Government needs to take policies to anticipate these problems through fiscal policy. One of the policies issued was the provision of income tax incentives article 21 to affected workers. The problems of this research cover the substance of government policies in providing income tax incentives article 21, and the impact of providing income tax incentives article 21 for workers. The research method used is a normative legal research method, with a statutory and conceptual approach to the problem. The technique of collecting legal materials is carried out by recording, identifying, inventorying, and compiling according to the types of available legal materials. Based on the research results, it was found that the provision of Article 21 income tax incentives and borne by the Government has specific requirements regarding the business category and the amount of salary of workers who have the right to get the incentives. This is regulated in the Minister of Finance Regulation and implementation instructions through a letter from the Directorate General of Taxes Number SE-47/PJ/2020. The impact of providing this incentive can increase workers' income because income tax of Article 21 is borne by the government and helps workers maintain purchasing power. Thus, it can be concluded that the provision of income tax article 21 which is borne by the government has a fairly good impact on workers who meet the criteria and requirements, so that workers can also get incentives that are appropriate to their work and are able to support their daily needs.
\end{abstract}

Keywords: Covid-19; Tax Incentives; Government policy; Income Tax Article 21; Taxpayer. 


\section{PENDAHULUAN}

Pajak merupakan salah satu sumber utama penerimaan negara yang dapat dipergunakan dalam membiayai pembangunan nasional Indonesia yakni mencerdaskan kehidupan bangsa menciptakan kesejahteraan umum, melindungi seluruh tumpah darah Indonesia, dan membantu melaksanakan ketertiban dunia serta perdamaian abadi (Nugroho \& Yuniza, 2012). Mengacu kepada UU 17/2003 mengenai Keuangan Negara, pendapatan negara merupakan seluruh penerimaan yang berasal tidak hanya dari bidang perpajakan, tetapi termasuk pendapatan negara yang bukan dalam kategori pajak serta dalam bentuk hibah sebagai penerimaan negara yang bersumber dari dalam dan dari luar negeri (Ayza, 2017). Ciri-ciri pajak diantaranya adalah pajak dipungut berdasarkan kekuatan undang-undang serta aturan pelaksanaannya (Brotodihardjo, 2008). Pemerintah memberlakukan UU 6/1983 rnengenai ketentuan umum perpajakan (KUP) dan terus diperbaharui hingga terakhir dengan undang undang No. 28/2007. Objek dari pajak adalah penghasilan, sehingga untuk mengatur secara khusus mengenai pajak penghasilan pemerintah menetapkan undang-undang Nomor 36 Tahun 2008 yang sejak dikeluarkan pertama kali telah mengalami perubahan ke empat sebagai undang undang pajak penghasilan. Sejak akhir tahun 2019 penerimaan negara mengalami penurunan dikala Pandemi Covid19 melanda dunia dan berimbas kepada masalah kesehatan, sosial dan ekonomi termasuk di Indonesia, pada kuartal kedua tahun 2020 Indonesia mengalami pertumbuhan minus 5,32\% dibandingkan dengan tahun sebelurnnya, dan diperkirakan akan masuk kepada resesi ekonomi pada Kuartal ketiga tahun 2020 (Muhyiddin, 2020).

Pemerintah telah mengeluarkan kebijakan kebijakan yang dianggap penting seperti Peraturan pemerintah pengganti undang-undang (Perpu) yang disebabkan kegentingan, Peraturan Presiden, serta Peraturan Menteri terkait untuk memberikan stimulus perekonomian menghadapi dampak pandemi covid-19 diantaranya adalah Kebijakan moneter dan fiskal. Salah satu kebijakan fiskal adalah insentif di bidang perpajakan yaitu pajak penghasilan pasal 21 kepada karyawan yang sangat terdampak. Pajak esensinya adalah bersifat memaksa untuk penerimaan negara (budgeter) dalam membiayai pengeluaran pengeluaran negara, namun di saat pemerintah melakukan tindakan penyelamatan perekonomian maka pajak dapat berfungsi sebagai pengatur (regulator) untuk mencapai tujuan tujuan tertentu pemerintah.

Berdasarkan uraian latar belakang di atas, maka penelitian ini difokuskan untuk mengetahui substansi kebijakan pemerintah dalam memberikan insentif pajak penghasilan pasal 21 kepada wajib pajak terdampak pandemi covid-19, dan untuk mengetahui dampak pemberian insentif pajak penghasilan pasal 21 bagi pekerja yang terdampak pandemi covid-19.

\section{METODE PENELITIAN}

Jenis penelitian yang dipergunakan adalah penelitian hukum normatif (Fajar \& Yulianto, 2009) studi kepustakaan yang terkait dengan bahan bahan hukum untuk menemukan aturan hukum, prinsip prinsip hukum, dan juga keterapan hukum mengenai kebijakan pemerintah dalam memberikan insentif pajak penghasilan pasal 21 kepada wajib pajak terdampak pandemi covid-19. Pendekatan yang digunakan dalam pemecahan masalah adalah pendekatan perundang-undangan (statute approach) yaitu pendekatan yang dilakukan dengan menelaah semua peraturan perundang-undangan yang bersangkutan dengan permasalahan yang sedang dihadapi. Adapun pendekatan konseptual yang juga digunakan (conceptual approach) merupakan pendekatan yang beranjak dari pandanganpandangan dan doktrin-doktrin yang berkembang dalam ilmu hukum. Digunakan juga pendekatan kasus yang berhubungan dengan permasalahan dalam penelitian ini. Sumber bahan hukum dalam penelitian ini adalah bahan hukum primer yaitu bahan hukum yang mempunyai kekuatan yang mengikat secara umum (perundang-undangan) atau mempunyai kekuatan mengikat bagi pihak yang berkepentingan. Bahan hukum sekunder memberikan penjelasan mengenai bahan hukum primer, misalnya literatur mengenai pemberian insentif pajak penghasilan pasal 21, serta tulisan ilmiah dari para ahli hukum yang dapat diakses melalui buku-buku dan media internet.

\section{HASIL DAN PEMBAHASAN}

\section{Substansi Kebijakan Pemerintah dalam Pemberian Insentif Pajak Penghasilan Pasal 21 kepada Para Pekerja sebagai Dampak Panderni Covid-19}

Dalam ketentuannya undang-undang Pajak Penghasilan $(\mathrm{PPh})$ telah mengatur tentang dasar pengenaan pajak penghasilan kepada subjek pajak terkait dengan penghasilan yang diterirna untuk 
satu tahun periode pajak (Bohari, 2019). Subjek pajak yang dimaksud dikenakan pajak jika memperoleh penghasilan pada periode pajak tertentu. Subjek pajak yang memperoleh penghasilan didefinisikan dalam undang undang Pajak penghasilan (UU PPh) sebagai wajib pajak. Wajib pajak dapat dikenakan pajak untuk penghasilan yang diperolehnya selama satu masa pajak atau setahun penuh dan dapat pula dikenakan pajak untuk penghasilan sebagian dari tahun pajak apabila kewajiban pajak subjektifnya dari awal atau berakhir dalam tahun pajak (Mardiasmo, 2016,163). Yang ditentukan sebagai subjek pajak adalah: 1) seseorang atau pribadi dan warisan belum dibagi dengan kata lain pengganti yang berhak atau dengan sebutan pewaris, 2). Badan, dari berbagai bentuk antara lain berbentuk perseroan terbatas (PT), komanditer (CV) dan bentuk bentuk badan lainnya serta, 3). Serta Bentuk Usaha Tetap (BUT). Berdasarkan UU 36/2008 Yang dimaksudkan sebagai objek pajak adalah segala bentuk penghasilan, dengan kata lain segala bentuk penghasilan yang dikategorikan dapat meningkatkan kemampuan ekonomis termasuk didalamnya bersumber dari dalam negeri serta dapat pula yang bersumber dari luar Negeri, yang dipergunakan untuk memenuhi kebutuhan konsumsi ataupun untuk menambah jumlah kekayaan yang telah dijabarkan dalam pasal 4 UU Nomor 7 tahun 1983.

Penghasilan dalam bentuk dan nama apapun yang diterima oleh pekerja dihasilkan dalam hubungan kerja dengan pihak pemberi kerja sesuai dengan ketentuan Undang-undang Pajak Penghasilan, pekerja dengan penghasilan diatas kriteria tertentu (PTKP) wajib rnemiliki Nomor Pokok Wajib Pajak (NPWP). Pegawai dengan NPWP dan telah melebihi PTKP diberlakukan pemotongan pajak dengan tarif tertentu dengan mengacu kepada ketentuan pada pasal 17 ayat (1), dengan tarif 5\% (lima persen) paling rendah dan tertinggi 30\%. Subjek pajak dari Pajak Penghasilan pasal 21, diantaranya pegawai, karyawan tetap maupun tidak tetap, pensiunan, serta Orang pribadi lainnya. Objek dari PPh pasal 21 mengatur pengenaan pajak penghasilan dari hubungan kerja yang dihasilkan antara dua pihak yakni antara pemberi kerja dan pekerja. Penghasilan yang digolongkan objek dari PPh pasal 21 diatur dalam ketentuan dalam pasal 4 UU36/2008 mengenai pajak penghasilan antara lain; Penghasilan yang diterima secara berkala; Penghasilan tidak tetap; Upah dalam bentuk harian, mingguan, satuan, dan borongan, honorarium, hadiah berbentuk uang, dan pembayaran lainnya sebagai imbalan.

Ketentuan besaran penghasilan yang dapat dikenakan pajak penghasilan kepada pegawai tetap berupa jumlah penghasilan kotor yang telah dikurangi seluruh biaya yang dikenakan, diantaranya biaya jabatan yang ditentukan sebesar maksimal enam juta setahun, iuran pensiun, dan dikurangi jumlah tanggungan pegawai dari acuan Penghasilan Tidak Kena Pajak (PTKP), ketentuan PTKP tahun 2016 hingga 2020 saat ini masih diatur pada peraturan Nomor PER-16/PJ/2016 yang dikeluarkan oleh Direktorat Jenderal Pajak. Penghasilan kotor yang diterima pekerja atau pegawai merupakan sejurnlah penghasilan yang diberikan oleh pemberi kerja kepada pekerja-nya sebagai akibat hubungan kerja yang disebut sebagai objek pajak sebelum dikurangi faktor faktor sebagai pengurang. Insentif PPh Pasal 21 ditanggung Pemerintah ini diberikan kepada para pekerja yang telah dipersyaratkan sebagaimana diatur didalam Peraturan yang dikeluarkan oleh Menteri Keuangan dengan Nomor 23/PMK.03/2020 dan telah diperbaharui beberapa kali hingga Nomor 110/Pmk.03/2020 mengenai ketentuan pemberian lnsentif pajak kepada wajib pajak yang terkena dampak Wabah Virus Corona dan teknis pelaksanaan peraturan menteri ini diwujudkan dalam surat edaran omor SE-47/PJ/2020 yang dikeluarkan oleh Direktur Jenderal Pajak (DJP) yang mengatur tentang mekanisme pelaksanaan dari klasifikasi lapangan usaha hingga bentuk pengawasan dari serangkaian Peraturan Menteri Keuangan terkait insentif pajak.

Ketentuan mengenai pekerja yang berhak mendapatkan fasilitas insentif Pajak Penghasilan Pasal 21 ditanggung Pemerintah (PPh Ps 21 DTP) adalah sebagai berikut: 1) Mendapatkan penghasilan dari pelaku usaha yang tel ah memiliki Klasifikasi lapangan usaha sebagaimana yang tertuang dalam PMK 86/2020; dan dikategorikan sebagai Perusahaan KITE dengan beberapa golongan izin tertenru; 2) Wajib Memiliki NPWP; dan; 3) Penghasilan kotor yang diterima Pekerja tidak melebihi dari Rp. 200.000.000,00 (dua ratus juta rupiah) disetahunkan namun bersifat tetap dan teratur. Pemberi kerja wajib memotong penghasilan pekerja untuk pajak penghasilan pasal 21 ( $\mathrm{PPh} \mathrm{Ps}$ 21) setiap bulannya mempergunakan acuan pada ketentuan tarif pasal 17 ayat (1) huruf a UU $\mathrm{PPh}$, dan pemotongan penghasilan yang diperuntukan untuk pengenaan pajak penghasilan Pasal 21 tersebut ditanggung oleh pemerintah. Pada saat pembayaran penghasilan pekerja oleh pemberi pekerja $\mathrm{PPh}$ Pasal 21 ditanggung pemerintah ini ini wajib dibayarkan sepenuhnya sebesar nominal pemotongan 
Pajak Penghasilan pekerja secara runai. Apabila yang menanggung PPH Pasal 21 ini adalah pemberi kerja sebagai beban untuk para pekerja maka PPh Pasal 21 DTP ini tidak dapat diperhitungkan sebagai penghasilan yang dikenakan pajak sejak masa April hingga Desember 2020.

\section{Dampak Pemberian Insentif Pajak Penghasilan Pasal 21 bagi Para Pekerja Terdampak Pandemi Covid-19}

Pemerintah Indonesia mengambil langkah langkah luar biasa untuk melindungi seluruh masyarakatnya dan perekonomian Indonesia di tengah mewabahnya covid-19. Selain kebijakan moneter kebijakan fiskal merupakan satu perangkat kebijakan utama pemerintah dalam menghadapi dampak wabah covid-19.kebijakan APBN 2020 yang diamanatkan oleh Presiden RI agar berorientasi kepada tiga hal yang sangat penting, ya.kni menjaga kesehatan seluruh masyarakat, meningkatkan daya beli masyarakat khususnya kepada golongan kurang mampu melalui program program berupa penguatan dan social safetynet atau perluasan jaring pengaman sosial, serta melindungi pelaku usaha dari keterpurukan yang dapat menga.kibatkan kebangkrutan usaha. Beberapa stimulus ekonomi dikeluarkan Pemerintah yang pertama secara khusus diarahkan ada percepatan belanja khususnya bantuan sosial dan belanja modal, mendorong sektor padat karya, perluasan kartu semba.ko serta insentif untuk sektor pariwisata dan kedua yang fokus pada penyediaan insentif paja.k senilai Rp 22,5 triliun untuk periode April hingga September 2020. Dan dukungan untuk komoditas tertentu termasuk instruksi Presiden Nomor 4 tahun 2020 yang mengatur percepatan pelaksanaan refocusing, realokasi, dan pelaksanaan pengadaan barang keperluan penanganan covid-19.

Intensitas pandemi yang terus meningkat dan dampaknya yang mengancam keselarnatan jiwa seluruh masyarakat secara luas, stabilitas perekonomian yang memasuki resesi di sektor keuangan mencipta.kan situasi kegentingan yang menjadi sebab cliterbitkannya Perpu Nomor 1/2020 sebagai landasan atau payung hukum dalam rnengambil tinda.kan percepatan dan luar biasa serta terkoordinasi dalam menghadapi dampa.k mewabahnya covid-19, termasuk didalamnya melalui pengadaan stimulus insentif perpajakan dengan jumlah Rp. 405 (empat ratus lima) triliun. Bauran kebijakan moneter dan sektor keuangan juga dioptimalisasi oleh otoritas untuk menangani dampak wabah covid-19 dan memitigasi pengaruhnya terhadap perekonomian Negara (Badan Kebijakan Fiskal Kementerian Keuangan, 2020). Dampak paling signifikan dari covid-19 diprediksi akan sangat mempengaruhi baseline penerimaan negara di bidang Perpajakan maupun Pendapatan Negara Bukan Pajak (PNBP). Di sisi penerimaan perpajakan diperkirakan mengalami penurunan. Penurunan penerimaan perpajakan dipengaruhi beberapa faktor antara lain: 1) Perubahan baseline realisasi perpaja.kan tahun 2019 dan perubahan asumsi ekonomi makro tahun 2020 termasuk adanya perang harga minyak; 2) Kebijakan stimulus perpajakan yang secara langsung mengurangi penerimaan perpajakan; 3) Potensi risiko recovery ekonomi tahun 2020 yang lambat sehingga tidak dapat mendorong kenaikan penerimaan perpajakan. Dengan mempertimbangkan kondisi-kondisi di atas maka pada tahun 2020 penerimaan dari sektor perpajakan akan mengalami penurunan yang tajam. Pemerintah mengeluarkan Peraturan Presiden (Perpres) Nomor 72 Tahun 2020 bertujuan meningkatkan anggaran belanja dalam penanganan dampak dari wabah Covid-19 dan program pemulihan ekonomi. Salah satu ketentuan terkait program pemulihan ekonomi adalah dengan memberikan kewenangan khusus kepada Menteri Keuangan dalam melakukan tindakan tindakan dalam memperbaharui rincian anggaran pembelanjaan dan anggaran pembiayaan negara.

Dalam Perpres 72/2020 terkait perubahan APBN yang dinyatakan di dalamnya adalah resiko penurunan jumlah pendapatan negara sebagai akibat dari perluasan serta perpanjangan terkait kebijakan insentif perpajakan bagi pelaku usaha dalam penanganan wabah Covid-19 sejak dikeluarkannya peraturan Presiden hingga Desember 2020. Adapun produk Kebijakan fiskal insentif perpajakan yang dimaksud adalah: 1) PPh 21 bagi wajib pajak yang ditanggung oleh pihak Fiskus;

2) Pembebasan PPh 22 badan tertentu termasuk BUMN dan Swasta, serta PPN impor khusus untuk alat kesehatan); dan 3) Percepatan restitusi Pajak pertambahan nilai (PPN). Program stimulus fiskal yang telah dirancang oleh Pemerintah dalam Perpres No 72/2020 (perubahan Perpres 54/2020) memiliki tujuan utama untuk penguatan penanganan Covid-19 dan terarah pada pemulihan ekonomi nasional termasuk kebijakan fiskal perpajakan, oleh sebab itu pemanfaatan stimulus perpajakan dalam bentuk insentif pajak hams mengarah kepada sasaran yang tepat dan secara maksimal dapat diserap secara baik sehingga stimulus yang dialokasikan dan dikeluarkan oleh Pemerintah dapat memberikan manfaat bagi masyarakat dalam meningkatkan perekonomian dikala menghadapi wabah covid-19 
yang masih belum dapat diperkirakan kapan akan berakhir. Rangkaian kebijakan kebijakan berupa undang undang dan peraturan peraturan pemerintah untuk mengatasi dampak pandemi covid-19 merupakan bentuk konsep akan kepastian hukum, yang merupakan asas asas dari ruang lingkup hukum nasional dan ruang lingkup hukum internasional yang menyiratkan kepastian bagi subyek hukum terkait akan hak dan kewajibannya (Atmadja \& Budiartha, 2019). Asas kepastian hukurn berarti bahwa sebagai negara berdasarkan hukum dengan landasan penyelenggaraan kekuasan negara mengutamakan fondasi dari peraturan perundang undangan, konsep keadilan serta kepatutan dalam setiap pengambilan kebijakan yang dikeluarkan agar tujuan hukum atau perangkat kebijakan tersebut berguna dan bermanfaat di dalam masyarakat. Konsep dari kemanfaatan diartikan sebagai "kebahagiaan" kepada tiap individu, dan hukum telah memenuhi tujuannyajika mampu menghadirkan kebahagiaan bagi masyarakat (Atmadja \& Budiartha, 2018).

Target pemerintah adalah para Pekerja yang menjadi sasaran pemberian Insentif PPh pasal 21 yang telah memenuhi ketenruan sesuai aturan dalam serangkaian Peraturan Nomor 23/PMK.03/2020, Nomor 44/PMK.03/2020, 86/PMK.03/2020 dan 101/PMK.03.2020. Serta peraturan pelaksanaannya yakni surat edaran Nomor SE-47/PJ/2020 yang dikeluarkan Direktur Jenderal Pajak. Insentif yang diberikan pemerintah kepada pekerja ini adalah benruk kebijakan Fiskal pemerintah dengan tujuan utama agar pekerja mampu bertahan menghadapi masa wabah covid-19 yang masih terjadi hingga saat ini di Indonesia dan seluruh dunia yang menyebabkan resesi ekonomi global. Stimulus berupa Insentif yang diberikan diharapkan sesuai dengan tujuan pemerintah. Adapun implikasi pemberian insentif bagi para pekerja: 1) Meningkatnya pendapatan bagi para pekerja selama periode kebijakan berlangsung, karena pajak terutang pekerja kini ditanggung sepenuhnya oleh Pemerintah, dan apabila ditanggung pemberi kerja maka insentif pajak PPh Pasal 21 wajib dibayarkan kepada pekerja; 2) Dengan adanya tambahan pendapatan maka dapat membantu pekerja dalam mempertahankan daya belinya sehingga mampu menghadapi dampak ekonomi dari pandemi covid-19.

\section{SIMPULAN DAN SARAN}

\section{Simpulan}

Berdasarkan uraian permasalahan dan pembahasan tersebut simpulan yang diambil antara lain:

1. Kebijakan yang dikeluarkan pemerintah wajib mengacu kepada ketentuan undang- undangan agar kebijakan dapat dilaksanakan dengan adil, merata, dan mempunyai kepastian hukum. Pemberian Insentif Pajak Penghasilan Pasal 21 ditanggung Pemerintah (PPh Pasal 21 DTP) mempunyai persyaratan khusus mengenai kategori usaha tertentu dan batasan besaran gaji maksimum para pekerja yakni Rp. 200.000.000 (dua ratus juta rupiah) setahun yang berhak mendapatkan insentif dan diarur dalam Peraturan Menteri keuangan diantaranya Nomor 23/PMK.03/2020, Nomor 44/PMK.03/2020, Nomor 86/PMK.03/2020 dan Nomor 101/PMK.03/2020 tentang insentif Pajak Untuk Wajib Pajak Terdampak Pandemi Coronavirus Disease 2019 dan petunjuk pelaksanaannya dilakukan melalui surat edaran oleh Direktorat Jenderal Pajak dengan Nomor SE-47/PJ/2020 tahun 2020.

2. Dampak positif atau Implikasi pemberian insentif PPh 21 kepada pekerja adalah: a). Dapat meningkatkan pendapatan pekerja, karena beban pajak yang terutang telah ditanggung oleh Pemerintah, dan apabila ditanggung pemberi kerja maka insentif pajak PPh Pasal 21 wajib dibayarkan kepada pekerja, b). dengan adanya tambahan penghasilan maka dapat membanru pekerja dalam mempertahankan daya beli di tengah pandemi covid-19. Kebijakan Pemerintah dalam pemberian insentif PPh Pasal 21 ditanggung pemerintah merupakan kebijakan Fiskal pemerintah yang bersifat positif kepada masyarakat dalam hal ini pekerja, yang dikeluarkan oleh pemerintah untuk mengatasi kemendesakan dari dampak pandemi covid-19.

3. Pajak berfungsi sebagai budgeter yakni sebagai penerimaan negara untuk membiayai pengeluaran pengeluaran negara, namun apabila terdapat suatu kemendesakan dan untuk menstabilkan perekonomian negara salah sarunya disebabkan dampak bencana pandemi COYID-19 yang melumpuhkan perekonomian maka perlu dikeluarkan kebijakan baik moneter dan fiskal diantaranya berupa insentif pajak untuk mengatasi permasalahan perekonomian disinilah fungsi pajak sebagai rnengatur (regulerend), sehingga terjadi keseimbangan antara fungsi penerimaan dan mengatur dalam menghadapi permasalahan perrnasalahan yang terjadi. 


\section{Saran}

Berdasarkan uraian permasalahan dan kesimpulan dari hasil penelitian, adapun saran yang hendak disampaikan yaitu:

a. Kebijakan yang dikeluarkan oleh pemerintah wajib dilandasi pada ketentuan perundang-undangan sehingga kebijakan kebijakan tersebut dijalankan dengan baik serta dilandasi oleh suatu kepastian hukum, dan diharapkan proses atau prosedur kebijakan dijalankan secara baik dan maksimal unruk mencapai rujuan yang dikehendaki oleh pemerintah.

b. Dengan ketidakpastian kapan akan berakhimya pandemi covid-19 maka pemerintah perlu mengkaji untuk kembali melakukan perpanjangan kebijakan pemberian insentif perpajakan kepada pekerja dan pemberi kerja melalui stimulus fiskal insentif perpajakan di tahun 2021 dengan harapan dapat mendongkrak kembali daya beli dan tingkat konsumsi masyarakat di tengah resesi ekonomi yang disebabkan Pandemi covid-19.

\section{DAFTAR PUSTAKA}

Atmadja, I. D. G., \& Budiartha, I. N. P. (2018). Teori-Teori Hukum. Malang: Setara Pers.

Atmadja, I. D. G., \& Budiartha, I. N. P. (2019). Sistematika Filsafat Hukum. Malang: Setara Pers.

Ayza, B. (2017). Hukum Pajak Indonesia. Jakarta: Kencana.

Badan Kebijakan Fiskal Kementerian Keuangan. (2020). Kerangka Ekonomi Makro dan Pokok Pokok Kebijakan Fiskal 2021- Percepatan Pemulihan Ekonomi Dan Penguatan Reformasi. Jakarta: Kementrian Keuangan Republik Indonesia.

Bohari. (2019). Pengantar Hukum Pajak. Depok: PT Raja Grafindo Persada.

Brotodihardjo, S. (2008). Pengantar Ilmu Hukum Pajak. Bandung: Refika Aditama.

Fajar, M., \& Yulianto, A. (2009). Dualisme Penelitian Hukum Normatif. Yogyakarta: Pustaka Pelajar. Muhyiddin. (2020). Covid-19, New Normal dan Perencanaan Pembangunan di Indonesia. The Indonesian Journal of Development Planning, IV(2), 240-252.

Nugroho, A. D., \& Yuniza, M. E. (2012). Pengaturan Pajak Daerah di Provinsi Daerah Istimewa Yogyakarta Dan Kota Yogyakarta. Mimbar Hukum, 24(1), 130-144.

Peraturan Menteri Keuangan Republik Indonesia Nomor 110/Pmk.03/2020 Tentang Perubahan Atas Peraturan Menteri Keuangan Nomor 86/Pmk.03/2020 Tentang lnsentif Pajak Untuk Wajib Pajak Terdampak Pandemi Corona virus Disease 2019 